\title{
Felszínen mozgó földikutyák - A földikutyák védelmének új kihívása
}

\author{
Németh Attila ${ }^{1,2^{*}}$, Schneider Viktor ${ }^{3}$, Váczi Olivér ${ }^{4}$ és Csorba Gábor ${ }^{5}$ \\ ${ }^{1}$ Debreceni Egyetem, Természetvédelmi Állattani és Vadgazdálkodási Tanszék, \\ 4032 Debrecen, Böszörményi út 138. \\ ${ }^{2}$ Magyar Madártani és Természetvédelmi Egyesület, 1121 Budapest, Költö u. 21. \\ ${ }^{3}$ Kiskunsági Nemzeti Park Igazgatóság, 6000 Kecskemét, Liszt F. u. 19. \\ ${ }^{4}$ Herman Ottó Intézet Nonprofit Kft., 1223 Budapest, Park u. 2. \\ ${ }^{5}$ Magyar Természettudományi Múzeum, 1088 Budapest, Baross u. 13. \\ *E-mail: dr.attila.nemeth@gmail.com
}

\begin{abstract}
Összefoglaló: A földikutyák talajlakó életmódja védelmet jelent számukra a legtöbb ragadozóval szemben, és a kedvezőtlen időjárási hatások is kevésbé hatnak így rájuk. Azonban a rendszeres terepi munkának köszönhetően hazánkból is mind több adat válik ismertté arról, hogy e különös rágcsálók felszíni tevékenységet is folytatnak. A szakirodalomban számos magyarázat található a felszíni előfordulással kapcsolatban. A járatrendszert elhagyó példányok számtalan veszélynek vannak kitéve, például könnyen zsákmányául eshetnek a felszíni ragadozóknak. Jelen munkánkban bemutatjuk a felszínen talált földikutyákról az elmúlt három évtizedböl rendelkezésre álló Kárpátmedencei adatokat. Ezek szerint leggyakrabban nyár elején találkozhatunk földikutyákkal a felszínen, jellemzően fiatal példányokkal. Mivel Magyarországon a földikutyák veszélyeztetett fajok, már egyetlen egyed pusztulása is pótolhatatlan veszteség lehet. Ugyanakkor a felszínre tévedt példányok összegyüjtésével alkalmas, védett területeken újabb állományok létrehozására nyílhat lehetőség. A veszélyek és lehetőségek megvitatásával ajánlásokat fogalmazunk meg a felszínen talált példányok kezelésére, melyek hozzájárulhatnak e fokozottan védett rágcsálók hatékonyabb védelméhez.
\end{abstract}

Kulcsszavak: Nannospalax (superspecies leucodon), felszíni aktivitás, intraspecifikus agresszió, veszélyeztető tényezők, fiatalkori szétterjedés, természetes ragadozók, áttelepítés

\section{Bevezetés}

Rejtett életmódú, ritka állatok tudományos vizsgálata kihívásokkal teli feladat, amely jelentős erőfeszítéseket és különleges módszertani megoldásokat is igényelhet (Henry et al. 2011, Blanc et al. 2013, Jambari et al. 2019). A kihalással fenyegetett fajok eredeti, természetes elterjedési területük jelentős részéről kiszorultak (Schnitzler 2011, Bocherens et al. 2015, Cooper et al. 2016), ezért a megmaradt populációk bizonyos (például ökológiai, élettani vagy akár genetikai) 
tulajdonságaik tekintetében gyakran csak töredékét őrizték meg fajuk egykori jellemzöinek (Bocherens et al. 2015, Fox et al. 2017, Suraprasit et al. 2020). Mindez nagyban nehezíti az illető fajok megismerését, vagy esetleg téves következtetések levonásához vezethet biológiájukat illetően (Kerley et al. 2012, Cooper et al. 2016, Fox et al. 2017). Ugyanakkor a kihalás szélén álló, de kevéssé ismert állatfajok esetében óriási jelentősége lenne a minél alaposabb megismerésüknek, hiszen a róluk rendelkezésre álló tudásanyag a megmentésüket szolgáló gyakorlati természetvédelmi beavatkozásokat alapozhatja meg.

Ez a probléma kifejezetten jellemző a nyugati földikutya fajcsoportba (Nannospalax [superspecies leucodon] Nordmann, 1840) sorolható fajok magyarországi állományaira is. A hazai földikutyákról rendelkezésre álló ismeretek - jelentős részben e különleges rágcsálók rejtett életmódja miatt - roppant hiányosak (Németh et al. 2013a). A máig fennmaradt, csekély számú és alacsony egyedszámú töredékpopulációk egyedeinek tanulmányozásával megszerezhető ismeretek esetében pedig félö, hogy inkább csak az adott állományt jellemzik, mintsem fajuk egészét. Ezért még napjainkban is születnek olyan felfedezések vagy éppen napvilágra kerülnek olyan problémák, melyek alapvetően befolyásolhatják az ezen veszélyeztetett rágcsálók megőrzéséért vívott küzdelmet.

A földikutyákat úgy ismerjük, mint a Nyugat-Palearktisz száraz, füves élőhelyeinek rejtett életmódú emlősállatait, melyek gyakorlatilag az egész életüket a föld felszíne alatt töltik (Topachevskii 1969, Vidacs et al. 2013). Szélsőségesen talajlakó életmódjuk és az ehhez kapcsolható morfológiai adaptációk eredményeként kialakult sajátos testfelépítésük miatt a hazai emlösfauna talán legkülönlegesebb tagjai (Vásárhelyi 1926). A magyarországi fajok ugyanakkor élőhelyeik átalakításának és megszünésének következtében a legveszélyeztetettebb gerinceseink közé tartoznak (Csorba et al. 2015, Németh et al. 2013), több állományuk megőrzése különösen nagy kihívást jelent az állami természetvédelem számára (Németh et al. 2020a).

Az egyik kiemelt jelentőségü, ám rendkívül veszélyeztetett populáció Albertirsa határában (Pest megye), több élőhelyfolton található (Németh et al. 2020b). A civil és az állami természetvédelem részéről egyaránt jelentős figyelmet élvező állomány élőhelyén többször figyeltek meg a felszínen mozgó földikutya-egyedeket. A földikutyák felszíni tartózkodásuk idején jelentős veszélynek vannak kitéve (Németh et al. 2016), ezért e jelenség természetvédelmi szempontból is jelentős kockázatot hordoz. 2020 nyarán egy kis kiterjedésü, alacsony egyedszámú élőhelyfolt közvetlen közelében két hét leforgása alatt három példányt találtak meg a felszínen, ami az egész töredékállomány 10-30\%-a is lehet. Mindez világosan megmutatja, mekkora természetvédelmi kockázatot jelenthet egy-egy állomány szempontjából az egyedek felszíni aktivitása. 
Bár a szakirodalom alapján úgy gondoljuk, hogy - ha csak tehetik - a földikutyák nem hagyják el felszín alatti otthonukat, az albertirsai példák jelzik, hogy ennek ellenére előfordul, hogy valamilyen okból egyes példányok a felszínre kényszerülnek. Cikkünkben összegyüjtöttük és értékeljük az elmúlt három évtizedből rendelkezésre álló, a földikutyák felszíni jelenlétével kapcsolatos valamennyi Kárpát-medencei adatot, és megvitatjuk, milyen veszélyeket és lehetőséget jelent mindez a veszélyeztetett hazai földikutyafajok megőrzése szempontjából. Ajánlásokat fogalmazunk meg a felszínen talált földikutya-egyedek kezelésére vonatkozóan, amelyek hozzájárulhatnak e fokozottan védett rágcsálók eddigieknél hatékonyabb védelméhez.

\section{Anyag és módszer}

A földikutyák felszíni tevékenysége jelentette természetvédelmi kockázat értékeléséhez összegyüjtöttük a jelenséggel kapcsolatos valamennyi, 1990 óta a Kárpátmedence vonatkozásában elérhető adatot. Ugyanakkor csak azokat az adatokat használtuk fel és értékeltük tovább, ahol az észlelés pontos helye és ideje mellett vagy a példány, vagy annak valamilyen származéka (pl. genetikai minta), vagy legalább egy, az állatot felismerhetően megörökítő fénykép állt rendelkezésre. A Magyar Természettudományi Múzeum Emlősgyüjteményének adatai mellett természetvédelmi őrök, valamint civil szervezetek munkatársainak feljegyzéseit, illetve jelentéseit használtuk. Az összegyüjtött adatok Magyarország, Szerbia (Vajdaság tartomány), valamint Románia (Erdély) területéről származtak. Amenynyiben rendelkezésre állt az információ a talált egyedekröl, rögzítettük, hogy fiatalok-e vagy felnőttek. A fiatalok terepi felismeréséhez támpont, hogy testtömegük jóval kisebb a felnőttekénél, Kárpát-medencei viszonyok között sosem haladja meg a 110 grammot; testük jóval karcsúbb, így a fejük és a végtagjaik a teljesen kifejlett (egy évnél idősebb) egyedekhez képest aránytalanul nagynak tünnek. Hasonlóan, amennyiben sor került a talált példány ivarának meghatározására, abban az esetben az egyed nemét is rögzítettük az adatbázisban.

Mivel az adatok (jellegükből és gyüjtésük módjából adódóan) kvantitatív elemzéseket csak korlátozott mértékben tesznek lehetővé, elsősorban kvalitatív értékelésüket végeztük el. A felszíni észlelések szezonalitását a százalékos megjelenési arányok egyenletes eloszlással való összehasonlításával, $\mathrm{Chi}^{2}$ teszttel elvégzett függetlenség vizsgálattal elemeztük, melyhez a GraphPad Instat 3.05 program (Graphpad software Inc., SanDiego, CA, USA) ingyenes verzióját használtuk. 


\section{Eredmények}

A vizsgált időszakban, vagyis 1990 és 2020 között, 27 olyan adatot tudtunk öszszegyüjteni, amelyek földikutya-egyedek felszíni aktivitásával kapcsolatosak (1. táblázat, 1. ábra). Ezek többsége (63\%-a), az utóbbi tíz évből származik. A 2000 előtti időszakból mindössze két egyed egyazon helyen és időben történt észlelése ismert.

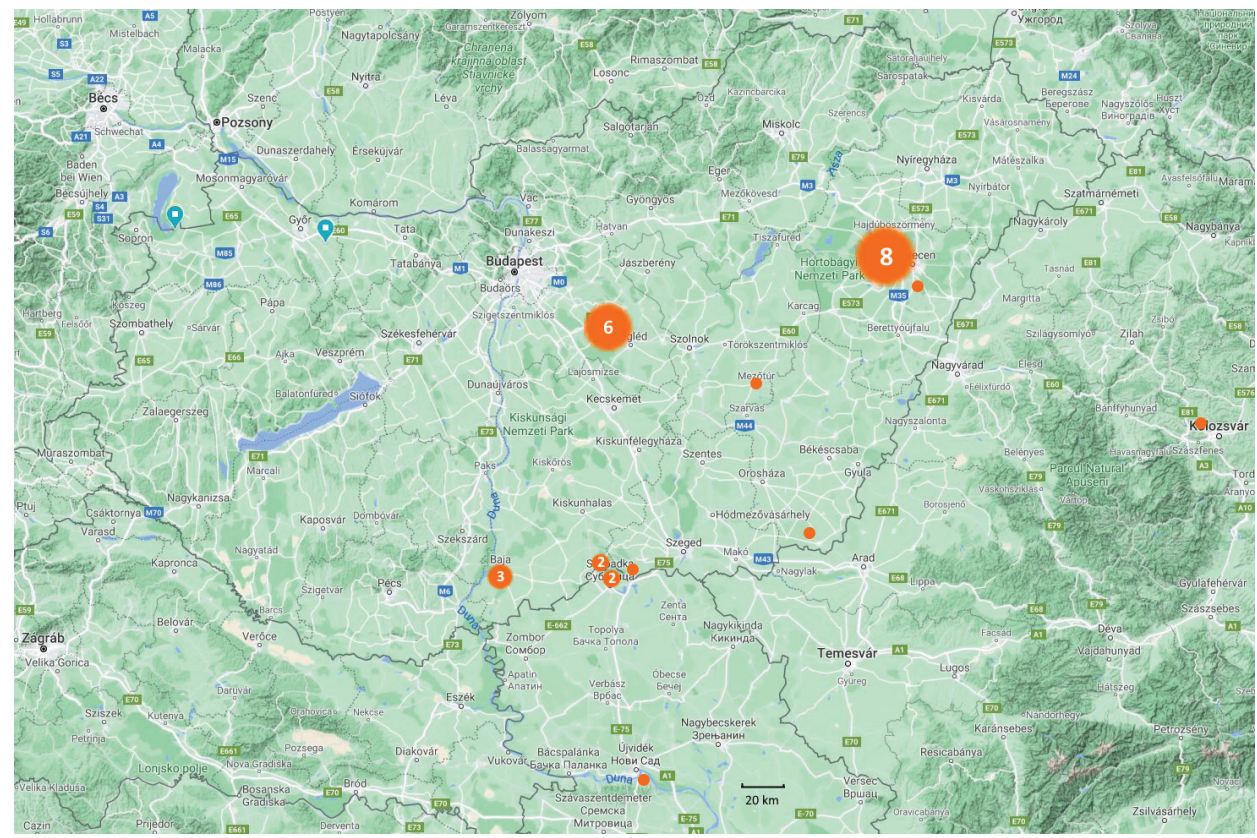

1. ábra. Az 1990 és 2020 között a Kárpát-medencében felszínen talált földikutya-egyedek térbeli eloszlása. A foltok átmérője arányos a megtalált egyedek számával. A szám nélküli foltok egyetlen felszínen talált egyedet jelölnek. Alaptérkép: Google, 2021.

A megtalált és azonosított korú egyedek $68 \%$-a fiatal példány volt, az ismert ivarú példányok többsége (mintegy $75 \%$-a) pedig hímnek bizonyult. A földikutyák felszíni észlelése döntően (az összes esetek 70\%-ában) a nyári hónapokra volt jellemzö, azon belül is a legtöbb megfigyelésre június és július hónapokban került sor (az összes esetek 59\%-a). Ugyanakkor az összegyüjtött adatok alapján minden évszakban előfordult legalább egy felszínen mozgó földikutya megfigyelése (2. ábra). A kifejlett állatok szezonalitása nem tér el szignifikánsan az egyenletes eloszlástól $\left(\mathrm{Chi}^{2}=6,47, \mathrm{df}=3, \mathrm{p}=0,091\right)$, míg a fiatal egyedek esetében eltért $\left(\mathrm{Chi}^{2}=65,30, \mathrm{df}=3, \mathrm{p}<0,0001\right)$. 
1. táblázat. Az 1990 és 2020 között a Kárpát-medencében felszínen talált földikutya-egyedek adatai. (A táblázat csak az ellenőrizhető észlelések adatait tartalmazza.)

\begin{tabular}{|c|c|c|c|c|}
\hline \multicolumn{2}{|c|}{ Megtalálás ideje } & \multirow[t]{2}{*}{ Megtalálás helye } & \multicolumn{2}{|c|}{ Megtalált példány } \\
\hline Év & Hónap & & Kora & Ivara \\
\hline 1991 & július & Kelebia & $?$ & $?$ \\
\hline 1991 & július & Kelebia & $?$ & $?$ \\
\hline 2003 & július & Debrecen-Józsa & fiatal & $?$ \\
\hline 2003 & július & Debrecen-Józsa & fiatal & $?$ \\
\hline 2005 & január & Debrecen-Józsa & felnőtt & hím \\
\hline 2005 & január & Debrecen-Józsa & felnőtt & $?$ \\
\hline 2005 & szeptember & Hajdúbagos & fiatal & hím \\
\hline 2005 & november & Debrecen-Józsa & felnőtt & $?$ \\
\hline 2008 & június & Mezőtúr & fiatal & hím \\
\hline 2009 & június & Debrecen-Józsa & felnőtt & nőstény \\
\hline 2011 & augusztus & Pétervárad/Petrovaradin & felnőtt & $?$ \\
\hline 2013 & február & Szabadka/Subotica & fiatal & $?$ \\
\hline 2013 & június & Baja & fiatal & $?$ \\
\hline 2016 & július & Ásotthalom & fiatal? & $?$ \\
\hline 2017 & március & Szabadka/Subotica & felnőtt & $?$ \\
\hline 2017 & április & Albertirsa & felnőtt & $?$ \\
\hline 2017 & június & Albertirsa & fiatal & $?$ \\
\hline 2017 & június & Baja & fiatal & $?$ \\
\hline 2017 & július & Baja & fiatal & $?$ \\
\hline 2019 & május & Tompapuszta & fiatal & hím \\
\hline 2019 & június & Kisbács/Baciu & fiatal & hím \\
\hline 2019 & július & Albertirsa & fiatal & $?$ \\
\hline 2020 & július & Albertirsa & fiatal & hím \\
\hline 2020 & július & Albertirsa & fiatal & nőstény \\
\hline 2020 & július & Albertirsa & fiatal & $?$ \\
\hline 2020 & augusztus & Debrecen-Józsa & felnőtt & $?$ \\
\hline 2020 & augusztus & Debrecen-Józsa & fiatal? & $?$ \\
\hline
\end{tabular}




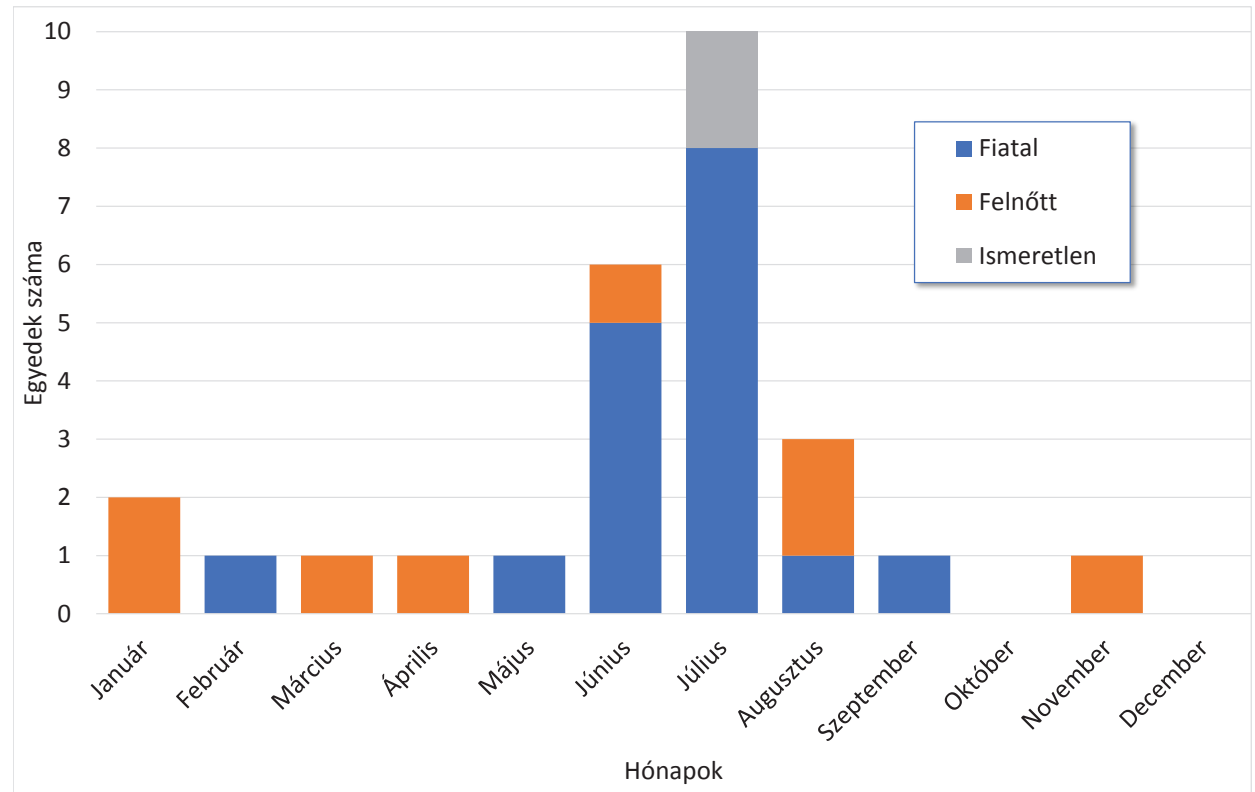

2. ábra. Az 1990 és 2020 között a Kárpát-medencében felszínen talált földikutya-egyedek időbeli eloszlása az év hónapjai során.

\section{Diszkusszió}

\section{Földikutyák a felszinen}

Bár a földikutyák hosszú önálló evolúciója jelentős részben arról szólt, hogy minél inkább függetleníteni tudják magukat a felszíni élettől (Topachevskii 1969, Nevo 1999, Vidacs et al. 2013), bizonyos körülmények között mégis a felszínen tevékenykednek (pl. Pocock 1917, Vásárhelyi 1926, 1929, Bate 1945, Nevo 1961, 1979, Heth 1991). A különböző szerzők különféle magyarázatokkal és elméletekkel szolgálnak e szokatlan viselkedésre. Némelykor a felszíni aktivitást szokatlan, szélsőséges időjárási események idején figyelték meg (Orosz 1906, Méhely 1909, Vásárhelyi 1926, 1929). Ilyenkor előfordulhat, hogy a szélsőséges időjárási események hatására az egyedek a felszín alatt nem találnak táplálékot maguknak, vagy nem képesek ahhoz hozzájutni. A földikutya-élőhelyeken jelentkező extrém nyári szárazság és aszály például nemcsak a tápláléknövényeket viseli meg (ezáltal csökkentve a táplálékkínálatot), de a talaj betonkeménységüre száradásával az ásást (vagyis a meglévő táplálékhoz való hozzájutást) is lehetetlenné teheti (Vásárhelyi 1926, 1929). A rendkívüli belvíz vagy áradás szintén a járatok elhagyására kényszeríti az állatokat (Sterbetz 1960, Horváth és Vadnay 2006). Különféle beszámolókat találhatunk a szakirodalomban a földikutyák táplálkozáshoz köthe- 
tő felszíni aktivitásával kapcsolatban is (Loisel 1916, Montagu 1924, Vásárhelyi 1926, Nevo 1961), de azt is megfigyelték, hogy a felszínen gyüjtenek friss füvet a fészekkamra kibéleléséhez (Vásárhelyi 1926, 1929). A kiásott fészekkamrák tanulmányozása során is beszámoltak arról, hogy abban felszínről származó növényi részek találhatóak (Sözen 2005, Yagci et al. 2010). Felmerült még a felszíni tevékenység okaként a fajtársak közötti agresszió (Vásárhelyi 1926, 1929, Zuri és Terkel 1996, Šklíba et al. 2016), valamint a betegség is (Vásárhelyi 1929). Feltehetően a leggyakoribb ok, ami miatt földikutya-egyedeket találunk a felszínen, a fiatalok elvándorlása lehet. A Kárpát-medencében általunk gyüjtött adatok között is a legtöbb a felszínen megtalált egyed fiatal példány volt, emellett több különböző országból közölt észlelés is beszámolt a fiatal földikutyák felszíni aktivitásáról (Vásárhelyi 1929, Nevo 1961, Topachevskii 1969, Heth 1991, Rado et al. 1992). Az önálló életet kezdő kölyköknek az anyaállat rendszerint leválasztja járatrendszerének egy részét, amiből kiindulva az utód képes saját járatrendszert építeni magának, fokozatosan eltávolodva a szülői otthontól (Rado et al. 1992). Hazai megfigyelések is alátámasztják, hogy ideális esetben, vagyis elegendő szabad élőhely esetén, a fiatalok elvándorlása, önállósodása a föld felszíne alatt történik (Moldován 2014), de ha erre nincs lehetőség (például túl nagy az egyedsürüség, vagy korlátozott méretü a rendelkezésre álló élőhelyfolt), akkor a fiatal állatok a felszínen vándorolva keresnek maguknak alkalmas helyet saját járatrendszerük megépítéséhez (Rado et al. 1992). Két szerző is beszámolt a fiatal földikutyák nagyobb számú felszíni jelenlétéről a szülőktől történő elválás időszakában (Vásárhelyi 1929, Nevo 1961). A fiatal földikutyák önállósodásának időszaka hazánkban jellemzően a nyár első felére, június, július hónapokra esik (Vásárhelyi 1929), mindez azonban az adott év időjárási eseményeinek függvényében korábban (május hónaptól) vagy akár később (akár augusztus hónapig) is bekövetkezhet. A Kárpát-medencében összegyüjtött, felszíni jelenlétre vonatkozó esetek többsége (78\%-a) a fiatalok elvándorlásához köthetö. A döntően kis kiterjedésủ és izolált hazai élőhelyek többségére jellemző a kifejezetten magas egyedsürüség (Németh et al. 2020a), ezért a fiataloknak szinte semmi esélyük nincs alkalmas, üres élőhelyet találni, és ezért fokozottabb mértékben rá vannak kényszerítve a felszíni vándorlásra. A felszíni jelenlétre vonatkozó esetek fennmaradó részének többségét (az összes eset 14\%-át) a párzási időszak idején (Vásárhelyi 1929) figyelték meg, ami minden bizonnyal a hímek ekkor vívott csatározásaihoz kapcsolható (Sklíba et al. 2016). Vásárhelyi $(1926,1929)$ véleménye szerint az intraspecifikus agreszszió a legfontosabb tényezö, ami a földikutyák felszíni tevékenysége mögött áll. Mivel mind a fiatalok felszíni elvándorlása, mind a párzás időszakában a felszínen való megjelenés erre az okra vezethető vissza (vagyis az általunk összegyüjtött adatok 85\%-a), az elmúlt 30 év Kárpát-medencei megfigyelései alátámasztják ezt az elképzelést. 


\section{Ismeretlen állományok indikátorai}

Számos, addig nem ismert földikutya-állomány azonosításához a felszínen talált egyedek vezettek. A mezőtúri állomány 2008-as megtalálása egy júniusi, a felszínen mozgó fiatal egyednek köszönhetö, a kelebiai populáció ugyanabban az évben történt azonosítása is a közel két évtizeddel korábban a felszínen talált földikutyák következményének tekinthető, és az albertirsai populáció 2017-es azonosításához is egy felszínen talált földikutya vezetett.

Mivel valószínüleg ma sem ismerjük az összes, még létező földikutya-állományt (Németh et al. 2020a), a még ismeretlen populációk felderítése érdekében is fontos lehet a nyár eleji időszakban országszerte, de kiemelten a földikutyák egykori előfordulási helyeinek közelében (Németh et al. 2009) fokozott figyelmet fordítani erre a jelenségre.

\section{Veszélyek a felszínen}

A talajlakó életmód alapvetően védelmet jelent a legtöbb ragadozóval szemben. Ismert ugyan olyan eset is, amikor a felszínen mozgó földikutya sikeresen meg tudta védeni magát a rá támadó ragadozóval szemben (Herman 1872), azonban a felszínre kerülő példányokat jellemzően nagy hatékonysággal zsákmányolják a felszíni ragadozók (Vásárhelyi 1926, Topachevskii 1969, Heth 1991, Németh et al. 2016; 2. táblázat). Az éjjel felszínre tévedő egyedekre baglyok vadásznak (kuvik, erdei fülesbagoly, gyöngybagoly, uhu), míg nappal szirti, héja-, pusztai és parlagi sas, gatyás-, egerész- és pusztai ölyv, valamint a kékes rétihéja, barna kánya és dögkeselyü fogyasztja a földikutyákat. Az említettek mellett további madárfajok, mint a fehér gólya, a sirályok, a szarka és a dolmányos varjú földikutya-zsákmányolása is ismert (Németh et al. 2016). A vadon élő emlősök közül a sakálon (Penezić és Ćirović 2015) és rókán kívül mindeddig elsősorban a menyétféle kisragadozók földikutya-zsákmányolásáról ismertek adatok (Németh et al. 2016). Az élőhelyek jelentős részének emberi településekhez közeli fekvése miatt (Németh et al. 2020a) a kóbor kutyák és macskák is fokozott veszélyt jelentenek a felszínen mozgó földikutyák számára (Németh et al. 2016).

A potenciális ragadozók terjedelmes listájából jól látható, hogy a huzamosabb időre felszínre kényszerült egyedeknek nem sok esélyük van a túlélésre, túlnyomó többségük valószínüleg elpusztul a felszíni tevékenység során. Különösen igaz lehet ez a hazai állományok esetében, ahol a jellemzően kis kiterjedésű, de magas egyedsürüségü élőhelyeken nem valószínü, hogy a territóriumot kereső fiatal földikutyák megfelelő élőhelyet találjanak. A hazai állományok rendkívül izolált, egymástól távoli élőhelyeken élnek, antropogén hatások uralta táji környezetben, ezért a fiataloknak aligha sikerül eljutniuk egy másik potenciálisan alkalmas élöhelyre azelőtt, hogy valamely ragadozó zsákmányává válnának, vagy akár gázolás áldozatai lennének (Csathó és Csathó 2009, Borza et al. 2021). 
2. táblázat. A felszínen tartózkodó földikutyákat fogyasztó ragadozók listája Németh et al. 2016 után. (A táblázat hivatkozásai az eredeti közleményben találhatók.)

\begin{tabular}{|c|c|c|c|c|}
\hline & Ragadozó faj & & $\begin{array}{l}\text { Vizsgálati hely- } \\
\text { szín }\end{array}$ & Hivatkozás \\
\hline \multirow[t]{30}{*}{ Baglyok } & kuvik & Athene noctua & Törökország & Kumerloeve 1955 \\
\hline & & & Izrael & Dor $1947 \mathrm{c}$ \\
\hline & & & Románia & $\begin{array}{l}\text { Aczél-Fridrich \& Hegyeli } \\
2009\end{array}$ \\
\hline & gyöngybagoly & Tyto alba & É-Libanon & Abi-Said et al. 2014 \\
\hline & & & DNy-Libanon & Obuk \& Benda 2009 \\
\hline & & & D-Szíria & Shehab 2005 \\
\hline & & & É-Szíria & Shehab \& Al Charabi 2006 \\
\hline & & & Ny-Szíria & Obuk \& Benda 2009 \\
\hline & & & Izrael & Charter et al. 2009 \\
\hline & & & & Nevo 1961 \\
\hline & & & & Dor 1947 b, c \\
\hline & & & & Heth 1991 \\
\hline & & & É-Izrael & Obuk \& Benda 2009 \\
\hline & & & & Tores et al. 2005 \\
\hline & & & Románia & $\begin{array}{c}\text { Aczél-Fridrich Zs., személyes } \\
\text { közlés }\end{array}$ \\
\hline & erdei & Asio otus & Izrael & Charter et al. 2012 \\
\hline & & & Libanon & Bate 1945 \\
\hline & & & Magyarország & Endes 1988 \\
\hline & & & Románia & Hamar \& Şutova 1965 \\
\hline & uhu & Bubo bubo & DNy-Törökország & De Cupere et al. 2009 \\
\hline & & & K-Törökország & Cermák et al. 2006 \\
\hline & & & Jordánia & Bates \& Herrison 1989 \\
\hline & & & Libanon & Bayle \& Prior 2006 \\
\hline & & & K-Ukrajna & Vetrov \& Kodratenko 2006 \\
\hline & & & & $\begin{array}{l}\text { Kodratenko \& Tovpients } \\
2006\end{array}$ \\
\hline & & & Ukrajna & Atamas \& Tovpinec 2006 \\
\hline & & & DNy-Oroszország & Malovichko et al. 2012 \\
\hline & & & Izrael & $\begin{array}{c}\text { Inbar személyes közlés in } \\
\text { Heth } 1991\end{array}$ \\
\hline & & & ÉK-Bulgária & Mitev \& Boev 2006 \\
\hline & & & Románia & $\begin{array}{l}\text { HNHM Mammal Collection, } \\
\text { Hegyeli személyes közlés }\end{array}$ \\
\hline
\end{tabular}


2. táblázat (folytatás). A felszínen tartózkodó földikutyákat fogyasztó ragadozók listája Németh et al. 2016 után. (A táblázat hivatkozásai az eredeti közleményben találhatók.)

\begin{tabular}{|c|c|c|c|c|}
\hline & Ragadozó faj & & $\begin{array}{l}\text { Vizsgálati hely- } \\
\text { szín }\end{array}$ & Hivatkozás \\
\hline \multirow[t]{25}{*}{$\begin{array}{l}\text { Ragadozó } \\
\text { madarak }\end{array}$} & dögkeselyü & $\begin{array}{c}\text { Neophron } \\
\text { percnopterus }\end{array}$ & Izrael & $\begin{array}{c}\text { Mendelssohn 1972a, b } \\
\text { Heth } 1988\end{array}$ \\
\hline & & & & $\begin{array}{l}\text { Levi, Shela személyes } \\
\text { közlés in Heth } 1991\end{array}$ \\
\hline & & & K-Bulgária & Milchev et al. 2012 \\
\hline & barna kánya & Milvus & Izrael & Mendelssohn 1972a, b \\
\hline & & migrans & $\begin{array}{l}\text { egykori Szovjet- } \\
\text { unió }\end{array}$ & Topachevskii 1969 \\
\hline & parlagi sas & Aquila heliaca & É-Szerbia & $\begin{array}{l}\text { Festetics in Glutz von } \\
\text { Blozheim et al. } 1971\end{array}$ \\
\hline & & & & Ham 1977, 1980 \\
\hline & & & & Vasic \& Misirlic 2002 \\
\hline & & & K-Ukrajna & Viter 2013 \\
\hline & & & Bulgária & Marin et al. 2004 \\
\hline & & & ÉNy-Törökország & $\begin{array}{c}\text { Horváth M. személyes } \\
\text { közlés }\end{array}$ \\
\hline & & & DNy-Oroszország & Malovychko 2012 \\
\hline & pusztai sas & $\begin{array}{l}\text { Aquila } \\
\text { nipalensis }\end{array}$ & $\begin{array}{l}\text { egykori Szovjet- } \\
\text { unió }\end{array}$ & Topachevskii 1969 \\
\hline & héjasas & $\begin{array}{l}\text { Hieraaetus } \\
\text { fasciatus }\end{array}$ & Izrael & Leshem 1976 \\
\hline & szirti sas & $\begin{array}{l}\text { Aquila } \\
\text { chrysaetos }\end{array}$ & Izrael & $\begin{array}{l}\text { Maninger személyes köz- } \\
\text { lés - in Heth } 1991\end{array}$ \\
\hline & pusztai ölyv & Buteo rufinus & Bulgaria & Vatev 1987 \\
\hline & & & Ukrajna & Kravchenko 2008 \\
\hline & & & & Shevtsov 2001 \\
\hline & & & Izrael & Aderet 1973 \\
\hline & & & & $\begin{array}{l}\text { Maninger személyes köz- } \\
\text { lés - in Heth } 1991\end{array}$ \\
\hline & egerészölyv & Buteo buteo & DNy-Ukrajna & Redinov 2009 \\
\hline & & & Ukrajna & Ponomarenko 2008 \\
\hline & & & & Redinov 2012 \\
\hline & gatyásölyv & Buteo lagopus & Románia & Chiocia 1967 \\
\hline & kékes rétihéja & Circus cyaneus & $\begin{array}{l}\text { egykori Szovjet- } \\
\text { unió }\end{array}$ & Topachevskii 1969 \\
\hline
\end{tabular}


2. táblázat (folytatás). A felszínen tartózkodó földikutyákat fogyasztó ragadozók listája Németh et al. 2016 után. (A táblázat hivatkozásai az eredeti közleményben találhatók.)

\begin{tabular}{|c|c|c|c|c|}
\hline \multicolumn{3}{|c|}{ Ragadozó faj } & Vizsgálati helyszín & Hivatkozás \\
\hline \multirow[t]{7}{*}{$\begin{array}{l}\text { Egyéb } \\
\text { madarak }\end{array}$} & \multirow[t]{2}{*}{$\begin{array}{l}\text { dolmányos } \\
\text { varjú }\end{array}$} & \multirow[t]{2}{*}{ Corvus cornix } & Izrael & $\begin{array}{c}\text { Ben-Yzhak, Ben-David } \\
\text { személyes közlés in Heth } \\
1991\end{array}$ \\
\hline & & & Románia & Herman 1872 \\
\hline & szarka & Pica pica & Magyarország & Vásárhelyi 1926 \\
\hline & $\begin{array}{l}\text { fehértorkú } \\
\text { halkapó }\end{array}$ & $\begin{array}{l}\text { Halcyon } \\
\text { smyrnensis }\end{array}$ & Izrael & $\begin{array}{c}\text { Inbar személyes közlés in } \\
\text { Heth } 1991\end{array}$ \\
\hline & $\begin{array}{l}\text { sárgalábú } \\
\text { sirály }\end{array}$ & $\begin{array}{l}\text { Larus } \\
\text { cachinnans }\end{array}$ & Ukrajna & Atamas \& Tovpinec 2006 \\
\hline & \multirow[t]{2}{*}{ fehér gólya } & \multirow[t]{2}{*}{$\begin{array}{l}\text { Ciconia } \\
\text { ciconia }\end{array}$} & Magyarország & $\begin{array}{c}\text { Dudás M., személyes } \\
\text { közlés }\end{array}$ \\
\hline & & & Ukrajna & $\begin{array}{c}\text { Archipov A., személyes } \\
\text { közlés }\end{array}$ \\
\hline \multirow[t]{10}{*}{$\begin{array}{l}\text { Emlős } \\
\text { ragadozók }\end{array}$} & \multirow[t]{2}{*}{ róka } & \multirow[t]{2}{*}{ Vulpes vulpes } & Románia & $\begin{array}{c}\text { Hegyeli Zs., személyes } \\
\text { közlés }\end{array}$ \\
\hline & & & egykori Szovjetunió & Topachevskii 1969 \\
\hline & aranysakál & Canis aureus & Szerbia & Penezić \& Ćirović 2015 \\
\hline & menyét & Mustela nivalis & Magyarország & Vásárhelyi 1926 \\
\hline & hermelin & $\begin{array}{l}\text { Mustela } \\
\text { erminea }\end{array}$ & Magyarország & Vásárhelyi 1926 \\
\hline & nyest & Martes foina & egykori Szovjetunió & Topachevskii 1969 \\
\hline & $\begin{array}{l}\text { közönséges } \\
\text { görény }\end{array}$ & $\begin{array}{l}\text { Mustela } \\
\text { putorius }\end{array}$ & Ukrajna & Abelentsev 1951 \\
\hline & molnárgörény & Mustela & Magyarország & Vásárhelyi 1926 \\
\hline & & eversmannii & Ukrajna & Abelentsev 1951 \\
\hline & tigrisgörény & $\begin{array}{c}\text { Vormela } \\
\text { peregusna }\end{array}$ & Israel & $\begin{array}{l}\text { Ben-David 1988, Gorsuch } \\
\text { \& Larivière 2005, Heth \& } \\
\text { Todrank } 1995\end{array}$ \\
\hline \multirow[t]{6}{*}{ Háziállatok } & \multirow[t]{2}{*}{ kutya } & \multirow[t]{2}{*}{$\begin{array}{l}\text { Canis lupus } \\
\text { familiaris }\end{array}$} & Magyarország & $\begin{array}{l}\text { Vásárhelyi 1926, } 1929 \\
\text { Németh et al. 2013b }\end{array}$ \\
\hline & & & Románia & Hegyeli személyes közlés \\
\hline & \multirow[t]{4}{*}{ házi macska } & \multirow{4}{*}{$\begin{array}{l}\text { Felis silvestris } \\
\text { catus }\end{array}$} & Izrael & Brickner-Braun et al. 2007 \\
\hline & & & egykori Szovjetunió & Topachevskii 1969 \\
\hline & & & Magyarország & $\begin{array}{c}\text { Csathó A., személyes } \\
\text { közlés }\end{array}$ \\
\hline & & & & Vásárhelyi 1926, 1929 \\
\hline
\end{tabular}


Felszinen talált földikutya-egyedek elhelyezésének megtervezése

A fokozottan védett, kihalás szélén álló földikutyafajok esetében az éves természetes szaporulat jelentős részének pusztulása pótolhatatlan veszteség a természetvédelem számára. Ezek az egyedek ugyanakkor megtalálásuk esetén, a földikutyák számára potenciálisan alkalmas, védett területeken kialakított újabb állományok forrását is jelenthetnék (Németh et al. 2013b). Elöre kidolgozott intézkedési tervet követő áttelepítésekkel az egyes földikutyafajok sérülékenysége számottevően csökkenthető, hosszútávú fennmaradásuk esélye pedig jelentősen növelhető, ezért fontos lenne, hogy a (potenciálisan) érintett nemzeti park igazgatóságok elöre térképezzék fel a szóba jöhető élőhelyeket, szükség esetén védettséget, a kezelési tervben a szükséges tevékenységeket rendelve a területekhez. A felszínen megtalált egyedek számára így kiválasztható lenne a megfelelő áttelepítési helyszín. Így életben maradásuk biztosítható volna, és képesek lennének kolonizálni olyan számukra alkalmas élőhelyeket, ahova önmaguktól, a mai tájhasználati gyakorlatok mellett nem tudnának eljutni. Az így létrejövő új populációk életképességének biztosabbá tétele érdekében ugyanakkor később, nagyobb állományokból történő kiegészítésre, „rátelepítésre” is szükség lehet. Ez utóbbi azonban nem jelent további problémát, ugyanis a „rátelepítés” eredményeképp csökken az eredeti élőhelyen a már saját territóriummal rendelkező egyedek száma, így a következő év szaporulatából kevesebb egyed kényszerül a felszínre, mivel egy részük a megüresedett területeket elfoglalhatja.

Több földikutya-élőhely közelében is zajlik már új populáció létrehozására irányuló természetvédelmi beavatkozás (3. táblázat). A már folyamatban lévő akciók helyszínei megfelelő élöhelyet jelenthetnek a saját populációikból elvándorolni

3. táblázat. Az ismert földikutya-élőhelyek közelében zajló, új populációk létrehozása érdekében történő földikutya-áttelepítések helyszíneinek listája. Az áttelepítési helyszínek a felszínen talált földikutya-példányok lehetséges elengedési helyszíneiként is szolgálhatnak.

\begin{tabular}{cc}
\hline Megtalálási helyek & Potenciális elengedési helyszín \\
\hline Hajdúbagos & Kék-Kálló mente, Bagamér, Malom-gát \\
Téglás & \\
további nyírségi homoki élőhelyek & \\
Debrecen, Nyulas & Pocsaji Érkapu (Löszletörés) \\
Józsa & \\
Hajdúsági löszhát további területei & Öttömösi Baromjárás \\
Kelebia & \\
Ásotthalom & Madarasi gyep \\
Bajai Földikutya Rezervátum
\end{tabular}


próbáló egyedek számára. Ezek a példányok ugyanakkor növelhetik a természetvédelmi beavatkozás sikerét is, hiszen így több alapító egyeddel rendelkezhet az új populáció. A felszínen megfigyelt földikutya-példányok többsége hím, ami azért fontos, mert a hímek aránya az alapító egyedek között kritikus tényező a sikeresség szempontjából (Ruzsa et al. 2020).

Javasolt intézkedési terv földikutya-egyedek felszínen történö megtalálása esetén A rendelkezésre álló adatok alapján a földikutyák felszíni jelenléte nem rendkívüli esemény. A legnagyobb valószínűséggel a nyári időszak első felében lehet velük találkozni, és ekkor is elsősorban fiatal példányokkal. Egyes állományok esetében az élőhely kis kiterjedése és erősen izolált jellege miatt indokolt lehet a felszínre kényszerülő példányok célzott keresése és összegyüjtése.

Felszínen talált földikutya esetén a legfontosabb tennivaló, hogy a példány számára mielőbb biztonságos, nyugodt körülményeket és táplálékot biztosítsunk. A fiatalok esetében ez egyébként is életük leginkább megterhelö időszaka, és valószínűleg a megtalálás idejére már jelentős stresszhatáson estek át az anyától való elválás, a testvéreikkel és más felnőtt egyedekkel folytatott csatározások, valamint a felszíni vándorlás okozta megpróbáltatások eredményeként. A befogott állatot a lehető legrövidebb időn belül zavarásmentes, zárt, hüvös, száraz helyiségben kell elhelyezni. A tartásra javasolt magas falú mủanyagládában szigorúan csak egy példány tartható, megfelelő minőségü, lehetőség szerint nem illatosított faforgácsban (nem fürészporban!). A ládákban lévő egyedeket mind a nagy melegtől, mind a tartós hidegtől óvni kell, számukra $20^{\circ} \mathrm{C}$ körüli hőmérsékletet kell biztosítani. A szakirodalom alapján (Gazit et al. 1996, Shanas et al. 1997, Zuri és Terkel 1998) nem szerencsés folyamatosan sötétben tartani az egyedeket, inkább a külső nappali-éjszakai fényviszonyoknak megfelelően a világos és sötét időszakok váltakozó biztosítása szükséges. A példányok táplálása friss zöldségekkel (burgonya, sárgarépa, petrezselyemgyökér, karalábé, zeller, saláta, retek, vöröshagyma, alma) valamint az élőhelyről származó tápláléknövények (pl. vadmurok, mezei iringó, ökörfarkkóró) gyökereivel valósítható meg (Németh et al. 2013a). A földikutya átmeneti, de biztonságos elhelyezéséről az illetékes nemzeti park igazgatóságnak kell gondoskodnia. Mivel a felszínen talált egyed túlélési esélyei minimálisak, az ilyen módon kézre került földikutya egyed kezelése a 348/2006. (XII. 23.) Korm. rendelet védett állatfajok védelmére, tartására, hasznosítására és bemutatására vonatkozó részletes szabályai szerint mentési szállításnak minősül, mely a mentőközpontba (nemzeti park telephelyére) érkezéséig, vagy az állatorvosi vélemény alapján történő elengedéséig tart. Ezért befogása, ideiglenes tartása a nemzeti park igazgatóságok számára nem igényel külön hatósági engedélyt. Amennyiben nem hivatásos természetvédelmi szakember találta meg a földikutyát, mielőbb értesíte- 
ni szükséges a területileg illetékes nemzeti park igazgatóságot, és a kiérkezésükig a telefonon keresztül tett útmutatásuk szerint célszerü eljárni. Az egyed biztonságba helyezését követően a nemzeti parki szakembereknek mielőbb értesíteni kell az Agrárminisztérium Természetvédelemért felelős Helyettes Államtitkárságának szakmai tanácsadó szervezeteként müködő Földikutya- és Ürgevédelmi Szakértői Csoportot (annak elnökét vagy titkárát; http1). A Szakértői Csoport, amely e sajátos rágcsálók hazai specialistáiból áll, ezt követően megállapítja az állat korát, nemét, egészségi állapotát, esetleg faji hovatartozását. A felszínen talált földikutya kora és a megtalálási körülményeinek ismeretében, és egy orvosi vizsgálatot követően lehet dönteni az állat további sorsáról. Mindez jelentheti a befogott egyed megtalálási helyen történő elengedését, illetve a befogott példány áttelepítését.

A május közepétől augusztus végéig terjedő időszakban felszínen talált egyedek esetében, az egyed korától függetlenül, semmiképpen sem javasolt az állatnak a megtalálási helyén való újbóli elengedése, hiszen ott - szabad territórium hiányában - biztos pusztulásra lenne ítélve. Ugyanez érvényes az év bármely szakában a felszínen talált fiatal egyed esetében, mivel joggal feltételezhető, hogy vagy az idősebb fajtársaival folytatott sikertelen küzdelem következményeként indult el új élőhelyet keresni magának, vagy a terület, amit az anyától való elválás után talált, idővel mégsem bizonyult alkalmas élőhelynek. Ezekben az esetekben nem szerencsés visszaengedése arra a területre, amit éppen elhagyni igyekszik, ezért a fiatal példányt új földikutya-populáció létrehozása érdekében történő áttelepítési akcióba javasolt bevonni.

A nyári időszakon kívül a felszínen talált kifejlett földikutya esetében azonban annak az élőhelyéről történő elmozdítása alapvetően nem indokolt. Ha az utódgondozási időszakban (március elejétől május közepéig) talált, utódokkal rendelkező nőstény egyedről van szó, befogása, begyüjtése is kerülendő, hiszen mielőbb vissza kell térnie utódaihoz, hogy táplálhassa őket. Ezeknek a nőstényeknek az azonosítása egyszerü, mivel az állatot felemelve, annak hasoldalán jól láthatóak az emlők, amik szoptatási időszakon kívül gyakorlatilag észrevehetetlenek a bundában. A táplálkozási vagy alomgyüjtési célból felszínre jövő kifejlett földikutya-egyed élőhelyéről történő elmozdítása sem indokolt, oda visszaengedhető. A párzás (januártól márciusig terjedő) időszakában a felszínen talált felnőtt hím egyedek befogása ugyanakkor mindenképp indokolt, de állatorvosi vizsgálat vagy sérülés esetén a szükséges kezelés - után eredeti élőhelyére visszahelyezhető. Célszerü a visszaengedett állat helyszíni őrzése addig, míg az a felszínen mozog, megvárva, hogy visszatérjen a számára biztonságot jelentő földfelszín alatti járatába. Nem javasolt az egyed járatba hatolását erőltetni, hagyni kell, hogy az állat magától tegye azt meg. A távozó földikutya mögött a járat talajjal, fü- 
csomóval való eltömése sem javasolt, az állatok ezt rendszerint rövid időn belül maguktól is megteszik.

Bármilyen további, problémás esetben a példány befogása és a körülmények - további szakértők bevonásával és a szükséges vizsgálatok elvégzésével történő - tisztázásáig tartó, hivatásos természetvédelmi szakemberek általi fogságban tartása javasolt, mely hatósági engedélyhez kötött, ennek beszerzéséról az érintett nemzeti park igazgatóságnak gondoskodni szükséges. Tipikusan ilyen eset a korábban ismeretlen élőhelyről előkerült példányoké, amikor kiemelt fontosságú a genetikai mintavétel, hiszen az állatok rokonsági viszonyai, faji hovatartozása másképp nem dönthető el.

A felszínen elpusztultan talált példányok, vagy a leggondosabb eljárás mellett is olykor előforduló, a befogást követő pusztulás esetén az esetleges okok kiderítése és a földikutyákról rendelkezésünkre álló, még mindig hiányos ismeretek bővítése érdekében szintén a Földikutya- és Ürgevédelmi Szakértői Csoportot szükséges értesíteni. A csoport szakértői tudnak segítséget nyújtani a tetem további vizsgálatának lehetőségei kapcsán, a megfelelő külső szakemberek bevonásával. A felszínen talált földikutya-tetemek kezelésére vonatkozó ajánlás a Kárpát-medencei nyugati földikutyakisfajok fajmegőrzési tervének mellékletében, a „Megtalált tetemek kezelése" cím alatt olvasható (Németh et al. 2013a). Az ilyen esetek pontos dokumentációja nagymértékben hozzájárulhat a hazai földikutyafajok jobb megismeréséhez.

Bár a fiatal földikutyák felszíni tevékenysége jelentős veszélyforrás a hazai földikutyák állományainak megőrzése szempontjából, a felszínen található példányok révén új populációk hozhatók létre, vagy velük a már korábban kialakított, de még kis egyedszámú populációk genetikailag megerősíthetők, jelentősen hozzájárulva így a Kárpát-medence bennszülött földikutyafajainak hosszútávú megőrzéséhez.

Köszönetnyilvánitás - Köszönettel tartozunk a Duna-Ipoly Nemzeti Park Igazgatóság, valamint az Albertirsa Barátainak Köre Természetvédelmi Csoport munkatársainak, amiért munkánkat nagymértékben segítették. További köszönettel tartozunk az adatgyüjtés során nyújtott sokrétủ és pótolhatatlan segítségért a Milvus Csoport Madártani és Természetvédelmi Egyesület és a „Palics-Ludas” Közvállalat munkatársainak.

\section{Irodalomjegyzék}

Bate, D. M. A. (1945): XIV. - Note on small mammals from the Lebanon Mountains, Syria. Journal of Natural History 12(87): 141-158. https://doi.org/10.1080/00222934508527500

Blanc, L., Marboutin, E., Gatti, S., Gimenez, O. (2013): Abundance of rare and elusive species: empirical investigation of closed versus spatially explicit capture-recapture models with lynx 
as a case study. The Journal of Wildlife Management 77(2): 372-378. https://doi.org/10.1002/ jwmg. 453

Bocherens, H., Hofman-Kamińska, E., Drucker, D. G., Schmölcke, U., Kowalczyk, R. (2015): European bison as a refugee species? Evidence from isotopic data on Early Holocene bison and other large herbivores in northern Europe. PloS ONE 10(2): e0115090. https://doi.org/10.1371/ journal.pone. 0115090

Borza, S., Godó, L., Csathó, A. I., Valkó, O., Deák, B. (2021): A közúti közlekedés természetkárosító hatása a magyarországi gerincesfaunára - Szakirodalmi áttekintés. Természetvédelmi Közlemények 27:1-17. https://doi.org/10.20332/tvk-jnatconserv.2021.27.1

Cooper, D. M., Dugmore, A. J., Gittings, B. M., Scharf, A. K., Wilting, A., Kitchener, A. C. (2016): Predicted Pleistocene-Holocene range shifts of the tiger (Panthera tigris). Diversity and Distributions 22(11): 1199-1211. https://doi.org/10.1111/ddi.12484

Csathó, A. I., Csathó, A. J. (2009): Elütött állatok Battonyán. CSEMETE Természet- és Környezetvédelmi Egyesület, Battonya - Szeged.

Csorba, G., Krivek, G., Sendula, T., Homonnay Z. G., Hegyeli, Zs., Sugár, Sz., Farkas, J., Stojnić N., Németh, A. (2015): How can scientific research change conservation priorities? - A review of decade-long research on blind mole rats (Rodentia: Spalacinae) in the Carpathian Basin. Therya 6: 103-121. https://doi.org/10.12933/therya-15-245

Fox, N. S., Wallace, S. C., Mead, J. I. (2017): Fossil Mustela nigripes from Snake Creek Burial Cave, Nevada, and implications for black-footed ferret paleoecology. Western North American Naturalist 77(2): 137-151. https://doi.org/10.3398/064.077.0202

Gazit, I., Shanas, U., Terkel, J. (1996): First successful breeding of the blind mole rat (Spalax ehrenbergi) in captivity. Israel Journal of Ecology and Evolution 42(1): 3-13. https://doi.org/10.1080 00212210.1996 .10688829

Henry, P., Henry, A., Russello, M. A. (2011). A noninvasive hair sampling technique to obtain high quality DNA from elusive small mammals. Journal of Visualized Experiments 49: e2791. https:// doi.org/10.3791/2791

Heth, G. (1991): Evidence of aboveground predation and age determination of the prayed, in subterranean mole-rats (Spalax ehrenbergi) in Israel. Mammalia 55(4): 529-542. https://doi. org/10.1515/mamm.1991.55.4.529

Herman, O. (1872): A Mezőség II. A Mezőzáh - Tóháti, továbbá Méhesi-, Báldi- és Mezősályitósorozat. Erdélyi Múzeum Egylet Évkönyvei 6 (1).

Horváth, R., Vadnai, R. (2006): A földikutya. Szabolcs-Szatmár-Beregi Természet- és Környezetvédelmi Kulturális Értékőrző Alapítvány, Fehérgyarmat, 20 p.

Jambari, A., Sasidhran, S., Halim, H. R. A., Mohamed, K. A., Ashton-Butt, A., Lechner, A. M., Azhar, B. (2019). Quantifying species richness and composition of elusive rainforest mammals in Taman Negara National Park, Peninsular Malaysia. Global Ecology and Conservation 18: e00607. https://doi.org/10.1016/j.gecco.2019.e00607

Kerley, G. I. H., Kowalczyk, R., Cromsigt, J. P. G. M. (2012): Conservation implications of the refugee species concept and the European bison: king of the forest or refugee in a marginal habitat? Ecography 35(6): 519-529. https://doi.org/10.1111/j.1600-0587.2011.07146.x

Loisel, G. (1916): Observations faites en Serbie sur le Spalax monticola serbicus (Méhely). Bulletin du Muséum d'histoire naturelle Paris 22: 71-73.

Moldován, O. (2014): Az erdélyi földikutya Nannospalax (leucodon) transsylvanicus új populációjának létrehozása és az első év tapasztalatai. MSc szakdolgozat. Debreceni Egyetem, Debrecen.

Montagu, I. (1924): On the burrow of the Rodent Spalax (Mesospalax). Proceedings of the Zoological Society 1924: 1153-1160. 
Németh, A., Révay, T., Hegyeli, Z., Farkas, J., Czabán, D., Rózsás, A., Csorba, G. (2009): Chromosomal forms and risk assessment of Nannospalax (superspecies leucodon) (Mammalia: Rodentia) in the Carpathian Basin. Folia Zoologica 58(3): 349-361.

Németh, A., Csorba, G., Farkas, J., Krnács, Gy., Molnár, A., Boldogh, G. Szelényi, B. (2013a): VM Fajmegörzési tervek: Kárpát-medencei Nyugati földikutya kisfajok (Nannospalax [superspecies leucodon]). VM Környezetügyért Felelős Államtitkárság, Budapest, 68 p.

Németh, A., Molnár, A., Szél, L., Horváth, T., Demeter, L. Csorba, G. (2013b): Hogyan telepítsünk át földikutyát? Módszertani megfontolások szélsőségesen talajlakó rágcsálók megmentéséhez. Természetvédelmi Közlemények 19: 15-33.

Németh, A., Csorba, G., Laczkó, L., Mizsei, E., Bereczki, J., Pásztor J. A., Petró P. Sramkó, G. (2020b): Multi-locus genetic identification of a newly discovered population reveals a deep genetic divergence in European blind mole rats (Rodentia: Spalacidae: Nannospalax). Annales Zoologici Fennici 57: 89-98. https://doi.org/10.5735/086.057.0110

Németh, A., Moldován, O., Szél, L. (2020a): Mindig útban? - Városias környezetben fennmaradt földikutya állományok megőrzésének kihívásai Magyarországon. Természetvédelmi Közlemények 26: 52-69. https://doi.org/10.20332/tvk-jnatconserv.2020.26.52

Nevo, E. (1961): Observations on Israeli populations of the mole-rat, Spalax ehrenbergi Nehring 1898. Mammalia 25: 127-144. https://doi.org/10.1515/mamm.1961.25.2.127

Nevo, E. (1979): Adaptive convergence and divergence of subterranean mammals. Annual Review of Ecology, Evolution, and Systematics 10: 269-308. https://doi.org/10.1146/annurev. es.10.110179.001413

Nevo E. (2007) Mosaic Evolution of Subterranean Mammals: Tinkering, Regression, Progression, and Global Convergence. In: Begall S., Burda H., Schleich C.E. (eds.): Subterranean Rodents. Springer, Berlin, Heidelberg, pp. 375-388. https://doi.org/10.1007/978-3-540-69276-8_28

Penezić, A., Ćirović, D. (2015): Seasonal variation in diet of the golden jackal (Canis aureus) in Serbia. Mammal Research 60(4): 309-317.

Pocock, R. I. (1917): The habits of the Syrian mole-rat. The field 129: 740.

Rado, R., Wollberg, Z., Terkel, J. (1992): Dispersal of young mole-rats (Spalax ehrenbergi) from the natal burrow. Journal of Mammalogy 73(4): 885-890. https://doi.org/10.2307/1382211

Ruzsa, J., Schneider, V., Farkas, J., Németh, A. (2020): A magyarországi földikutya-áttelepítések értékelése. Természetvédelmi Közlemények 26: 70-92. https://doi.org/10.20332/tvk-jnatconserv.2020.26.70

Schnitzler, A. E. (2011): Past and present distribution of the North African-Asian lion subgroup: a review. Mammal Review 41(3): 220-243. https://doi.org/10.1111/j.1365-2907.2010.00181.x

Shanas, U., Shalgi, R., Terkel, J. (1997): Seasonal changes in the ovary of the blind mole rat (Spalax ehrenbergi). Israel Journal of Zoology 43(2): 149-158. https://doi.org/10.1080/00212210.1997 .10688899

Šklíba, J., Lövy, M., Koeppen, S. C., Pleštilová, L., Vitámvás, M., Nevo, E., Šumbera, R. (2016): Activity of free-living subterranean blind mole rats Spalax galili (Rodentia: Spalacidae) in an area of supposed sympatric speciation. Biological Journal of the Linnean Society 118(2): 280291. https://doi.org/10.1111/bij.12741

Sözen, M. (2005): A biological investigation on Turkish Spalax Guldenstaedt, 1770 (Mammalia: Rodentia). Gazi University Journal of Science 18(2): 167-181.

Sterbetz, I. (1960): Szabadföldi és laboratóriumi vizsgálatok a földikutyán. Állattani Közlemények 47: $151-158$.

Suraprasit, K., Jaeger, J. J., Shoocongdej, R., Chaimanee, Y., Wattanapituksakul, A., Bocherens, H. (2020): Long-term isotope evidence on the diet and habitat breadth of Pleistocene to Holocene 
caprines in Thailand: implications for the extirpation and conservation of Himalayan gorals. Frontiers in Ecology and Evolution 8: 67. https://doi.org/10.3389/fevo.2020.00067

Topachevskii, V. A. (1969): Fauna of the USSR: Mammals. Mole rats, Spalacidae. Smithsonian Institution and the National Science Foundation, Washington.

Yagci, T., Coskun, Y., Asan, N. (2010): The tunnel structure of blind mole rats (genus Spalax) in Turkey. Zoology in the Middle East 50: 35-40. https://doi.org/10.1080/09397140.2010.10638409

Vásárhelyi, I. (1926): Adatok a földikutya (Spalax hungaricus hungaricus Nhrg.) életmódjának ismeretéhez. Állattani Közlemények 23: 169-226.

Vásárhelyi, I. (1929): A magyar földikutya életmódja. Növényvédelem 5: 185-186.

Vidacs, J. A., Farkas, J. Németh, A. (2013): Konvergenciák, divergenciák és adaptáció a talajlakó életmódot folytató emlősöknél. Állattani Közlemények 98: 21-46.

Zuri, I., Terkel, J. (1998): Ontogeny of agonistic behaviour in dispersing blind mole rats (Spalax ehrenbergi). Aggressive Behavior 24(6): 455-470.

Zuri, I., Terkel, J. (1996): Locomotor patterns, territory and tunnel utilization in the mole-rat Spalax ehrenbergi. Journal of Zoology London 240: 123-140. https://doi.org/10.1111/j.1469-7998.1996. $\underline{\mathrm{tb} 05490 . \mathrm{x}}$

Hivatkozott jogszabályok:

348/2006. (XII. 23.) Korm. rendelet a védett állatfajok védelmére, tartására, hasznosítására és bemutatására vonatkozó részletes szabályokról

Internetes források:

http1: http://www.termeszetvedelem.hu/foldikutya-es-urgevedelmi-szakertoi-csoport 


\title{
Above-ground activity of blind mole rats - New challenges for blind mole rat protection in Hungary
}

\author{
Attila Németh ${ }^{1,2^{*}}$, Viktor Schneider ${ }^{3}$, Olivér Váczi ${ }^{4} \&$ Gábor Csorba $^{5}$ \\ ${ }^{1}$ University of Debrecen, Department of Nature Conservation, Zoology and Game \\ Management, H-4032 Debrecen, Böszörményi u. 138, Hungary \\ ${ }^{2}$ BirdLife Hungary - Hungarian Ornithological and Nature Conservation Society, \\ H-1121 Budapest, Költö u. 21, Hungary \\ ${ }^{3}$ Kiskunsági National Park Directorate, H-6000 Kecskemét, Liszt F. u. 19, Hungary \\ ${ }^{4}$ Herman Ottó Institute Non-profit Ltd., H-1223 Budapest, Park u. 2, Hungary \\ ${ }^{5}$ Hungarian Natural History Museum, H-1088 Budapest, Baross u. 13, Hungary \\ ${ }^{*}$ E-mail:dr.attila.nemeth@gmail.com
}

Living underground protects blind mole rats from most of the predators and unfavourable climate conditions. However, more and more observations of aboveground activity of these subterranean rodents are made in Hungary as well. Several reasons for such behaviour can be found in the literature. At the same time, individuals on the surface are exposed to numerous threats and can easily fall prey to surface predators. We present all the data available from the last three decades about the aboveground activity of blind mole rats from the Carpathian Basin. Based on these, they are most often above-ground in early summer, with typically young specimens venturing to the surface. However, blind mole rats in Hungary are directly threatened by extinction, and in the case of such an animal, even the death of a single individual is an irreparable loss. At the same time, by collecting these aboveground individuals, it may be possible to establish new populations in suitable protected areas. By discussing the hazards and opportunities, we make recommendations for the treatment of specimens found on the surface that could contribute to the more effective protection of these highly threatened rodents.

Keywords: Nannospalax (superspecies leucodon), aboveground activity, intraspecific aggression, threatening factors, juvenile dispersal, natural predators, translocation 